\title{
Intermediary Bodies of Governance
}

\begin{abstract}
Following the phase of conquest, usually a temporary interim government was formed to supervise the incorporation of newly acquired territories. The timing of the incorporation, as well as the manner in which models from other parts of Europe were applied, influenced how Napoleonic governance worked out in practice. Importantly, the creation of so-called gouvernements généraux became a Napoleonic integration instrument. General-Governors Charles-François Lebrun in Amsterdam and Louis Nicolas Davout in Hamburg had similar tasks but made different choices. Their relationships with other actors, local and French, differed as well. In this chapter the two intermediary bodies are discussed, in relation to other Napoleonic institutions and their main protagonists. Often, Napoleonic officials who had already proven their worth elsewhere were employed in these areas. Thus, institutional examples and personal experiences from other parts of the Empire, such as Italy, influenced the integration of the North. Yet, being remote from the imperial core, many officials competed for power and hence for control of the integration process.
\end{abstract}

Keywords Intermediary government • Incorporation • Integration • Charles-François Lebrun • Louis-Nicolas Davout 


\section{From Conguest to InCORPORATION}

During the autumn of 1810, Napoleon issued decree after decree to enlarge his Empire by incorporating conquered lands. In previous years, the treatment of new territorial acquisitions had been increasingly formalized. Usually an ephemeral Governor was appointed, certainly when it concerned small areas. Larger additions received more durable transitional forms of governance.

This chapter discusses how such intermediary governments were set up in the Dutch and Northwest German departments. In Amsterdam and Hamburg high state representatives were appointed, a Grand Dignitary and a Marshal respectively, aided by numerous high officials, which demonstrated that Napoleon was keen to integrate these lands firmly into the Empire. Both intermediary bodies of governance were given the task of implementing French institutions and procedures, but simultaneously had to establish working relationships with the former authorities. However, acts of French high officials, and the outcomes thereof, were all but uniform. Moreover, the governments were internally divided, and their relationships with other actors were equally complex.

Before investigating developments in the North, attention is paid to the expanding Empire on a larger scale. The introduction of the Napoleonic governance in lands that were conquered and occupied in 1810 could draw on earlier empire-building. These experiences served as steppingstones for the réunion of the Netherlands and Northwest Germany. Whereas the former commissioners of the French Republic in the Belgian and Rhenish departments had essentially been civil servants, from Napoleon's rule onward, generals were quasi-systematically appointed as administrators in occupied territories in the phase before incorporation or the creation of a vassal state. Indeed, many members of the extended Bonaparte family were military men, like Murat, Jérôme, and Louis. ${ }^{1}$ The practice was further institutionalized during the Empire. Specifically the creation of gouvernements généraux headed by an imperial Grand Dignitary was a Napoleonic instrument of incorporation.

\footnotetext{
${ }^{1}$ Jean-Paul Bertraud, 'L'armée au service de la politique extérieure de Napoléon', in: T. Lentz ed., Napoléon et l'Europe (Paris 2005) 171-172.
} 


\section{INSTRUMENTS OF EMPIRE-BUILDING: The GOUVERNEMENTS GÉNÉRAUX}

The Napoleonic idea of a General-Government can be traced be to the French conquest of northern Italy, specifically Piedmont, Tuscany, and Liguria. The French had especially had great hopes of Piedmont and Tuscany. After the conquest, the matter of how to achieve a more stable form of governance became pressing. Napoleon was uncertain how to deal with Piedmont, but eventually decided on its incorporation into France. Initially, Piedmont was administered by an intermediary body of governance known as the Consultà, overseen by French Commissioner-General Jean-Baptiste Jourdan. Its responsibility was to help transform the region into a cluster of French departments. On 11 September 1802, the Gouvernement général des départemens au-delà des Alpes was created, whereby conquered Piedmont was formally incorporated and six, eventually five, new departments were created from it (Doire, Sésia, Pô, Marengo, and Stura). General Jacques-François de Menou acted as GeneralGovernor of the Transalpin departments. ${ }^{2}$

Directly south of Piedmont lay the Ligurian Republic. Napoleon incorporated this vassal state in June 1805, and three new departments were created: Apennins, Montenotte, and Gênes. The western part of the former republic was added to the existing department Alpes-Maritimes. The introduction of the French administration took place under the responsibility of Ministry of the Interior. But on the spot, from Genoa, CharlesFrançois Lebrun acted as General-Governor. He made serious efforts to create support among Italians. The Governor and his direct collaborators noted that seeking good harmony with the local elite was an effective integration strategy. Lebrun was critical of the French army, and also had conflicts with police minister Joseph Fouché. With the outbreak of the Third Coalition War, French troops were concentrated in northern Italy. However, a subsequent uprising in Piacentino, which threatened to spread to Genoa and surroundings, made Napoleon lose his confidence in Lebrun. Lebrun had suppressed the uprising but was mild in his punishments, which irritated the Emperor enormously. Lebrun stood up for his

\footnotetext{
${ }^{2}$ Michael Broers, The Napoleonic Mediterranean: Enlightenment, revolution and empire (e-book ed.; London and New York 2019). https://doi.org/10.5040/9781350988958
} 
cause and defended his moderate stance. ${ }^{3}$ The Ligurian departments were thereupon added to the General-Government of the Transalpine Departments under the supervision of General Menou. Lebrun returned to France.

Several Italian territorial entities were thus merged into a Transalpin collective, which formed the blueprint for a new type of grand dignitaire. A sénatus-consulte organique created the gouverneur général as a state representative next to the extant Grand Dignitaries. On 8 February 1808, in the Senate, member of the Council of State Jean-Baptiste Treilhard legitimized the introduction of an additional Grand Dignitary-created specifically for the incorporated regions-as followed: 'The institutions of peoples should always be useful to their position, to their current needs'. Experience showed, Treilhard stressed, that every day the Grand Dignitaries prove the usefulness as 'sublime intermediaries between the monarch and the peoples'. By creating the Grand Dignitary of gouverneur général of the Transalpine departments, Napoleon aimed to improve the bond between his person and his subjects, according to Treilhard. The deeds of the General-Governor, should lead to a better communication between 'the father of the state and the children separated from him by long distances and natural obstacles'. ${ }^{4}$

Napoleon's brother-in-law Camillo Borghese, married to Pauline Bonaparte, was appointed General-Governor of the Transalpin departments. The Emperor also created a Grand Dignitary-type gouverneur général for Tuscany. From Florence, Napoleon's Elisa Bonaparte governed this part of Italy, but her power as General-Governor and Grand Duchess over Tuscany (Arno, Ombrone, and Méditerranée) was very restricted by her brother. Likewise, Borghese had little success. Most Piedmontese nobles, still loyal to the Savoyard dynasty, did not rally to the French. Elisa had some more local goodwill, but too little influence in Paris to exert any serious power. ${ }^{5}$ After Camillo Borghèse and Elisa

${ }^{3}$ Adeline Beaurepaire-Hernandez, 'Un modèle de notable européen? Les 'masses de granit' des départements liguriens et leur intégration au système impérial', in: F. Antoine et al. ed., L'Empire napoléonien. Une expérience européenne? (Paris 2014) 349-356; Michael Broers, The Napoleonic empire in Italy, 1796-1814: Cultural imperialism in a European context? (Basingstoke 2005) 95, 99; A. E. M. Ribberink, 'Lebrun en de homines novi', Nederlands Archievenblad XC (1986) 132-133.

${ }^{4}$ Lewis Goldsmith, Recueil de décrets, ordonnances, traités de paix, manifestes, proclamations, discours, éc. III (London 1813) 257-258.

${ }^{5}$ Broers, The Napoleonic Mediterranean. 
Bonaparte, Charles-François Lebrun would in 1810 become the third General-Governor of this type.

Concurrently, numerous other territories were added to the Empire and many smaller intermediary governments briefly existed. A remarkable case are the Illyrian Provinces, formed in October 1809 from territories ceded from the Austrian Empire. Newly created Illyria was never fully integrated into the French Empire. Instead of departments, seven intendances were created; some French institutions were introduced but legally it remained a distinct entity. Several generals were successively appointed Governor. Eventually, the geographical and mental distance to Paris was too great to achieve further integration. ${ }^{6}$ Equally remarkable are the shortlived Catalan departments that were formally incorporated in January 1812. But in Catalonia the integration process had little time to take off. In the four Catalonian departments created on paper, the French effectively exercised only control over the two enclaves Barcelona and Girona, and their immediate environs. ${ }^{7}$

In brief, intermediary bodies of governance became widespread during the Empire. Gradually regional systems of governance were harmonized, thus stimulating integration. Only the Illyrian provinces and Catalonia deviated from the trend, due to military factors at the end of the Napoleonic wars. ${ }^{8}$ On the whole, many of the intermediary governments worked with care, were intent on entrenching the system they imported by taking into account past institutions and soliciting local notables to ensure cooperation. Nevertheless, outside of Old France it was sometimes necessary to bend the rules more than might initially have been considered desirable. ${ }^{9}$

Rule-bending was certainly the case in the North, which would lead to significant clashes within the state apparatus. From a constitutional point of view, the Dutch departments and those in Northwest Germany were incorporated into the French Empire on 13 December 1810 via a sénatusconsulte organique. Thus the imperial population increased by more than

\footnotetext{
${ }^{6}$ Josip Kolanović and Janez Šumrada ed., Napoleon et son administration en adriatique orientale et dans les Alpes de l'est, 1806-1814 (Zagreb 2005) 21-41.

${ }^{7}$ Broers, The Napoleonic Mediterranean.

${ }^{8}$ Helmut Stubbe da Luz, 'Gouverneure, Prokonsuln, Satrapen, Vizekönige. Bemerkungen zur politischen Top-down-Substitution und -Delegation. Einführung', in: H. Stubbe da Luz ed., Statthalterregimes-Napoleons Generalgouvernements in Italien, Holland und Deutschland (1808-1814) (Hamburg 2016) 10-11, 23-24.

${ }^{9}$ Aurélien Lignereux, L’Empire des Français: 1799-1815 (Paris 2012) 356-357.
} 
three million inhabitants. However, the legal texts said little about the actual reorganization of the northern periphery. ${ }^{10}$

\section{General-Governors: Lebrun and Davout}

Lack of clear provisions, evidently, gave the Emperor leeway to organize his Empire primarily by decree. Two months earlier, on 18 October 1810 , Napoleon had already issued a decree organizing Dutch departments, laying the foundations for Napoleonic governance in the Netherlands. ${ }^{11}$ It was based on the organization of the Italian Transalpin departments, and envisioned a gouperneur général at the top, assisted by a number of high officials. The General-Government had to function as an intermediary between the Dutch departments and the central government in Paris-in accordance to the spirit of the Grand Dignitaryship of the GeneralGovernor, as determined in 1808. The gouverneur général was to have almost absolute control over civilian and military affairs in the Dutch departments. Except for the Emperor, no one was higher in hierarchy. 'Holland' was divided into seven departments which were to be organized along French lines. During the talks in Paris the Dutch had advised to include the departments south of the Rhine, which had belonged to the Kingdom of Holland up till March 1810. But this idea was rejected. The Rhine remained a mental border within the Empire.

As Lieutenant General, 71-year-old Charles-François Lebrun was certainly a man most suited for the job. Charles-François Lebrun had many years of political experience. He had started his career under Louis XV. During the French Revolution he took the Tennis Court Oath, and in 1794 narrowly escaped death by guillotine. Lebrun was a financial expert. His skills and knowledge contributed to his elevation to Third Consul in 1799, next to Bonaparte and Cambacérès. With the establishment of the Empire in 1804, Lebrun was appointed archi-trésorier (arch-treasurer) of the French Empire. Though his title was mainly ceremonial, Lebrun was most influential. Moreover, Lebrun had been gouverneur général in northern Italy during the incorporation of the Ligurian Republic. As said, during a time of popular uprisings, Lebrun had been willing to listen to the concerns of the local elite, which was not always appreciated by the

${ }^{10} \mathrm{~J}$. B. Duvergier, Collection complète des lois, décrets, ordonnances, réglemens et avis du Conseil-d'État, depuis 1788 jusques et y compris 1824. Tome dix-septième (Paris 1826) 264.

${ }^{11}$ Ibid., 209-227. 
Emperor, nor by the repressive forces in Italy, such as the police and the military. ${ }^{12}$

Lebrun mediated between France and the Netherlands. His task was to supervise Dutch high officials and to improve communication. CharlesFrançois Lebrun started an intensive and amicable correspondence with former co-Consul Cambacérès, who-when Napoleon was not in Parisacted as the head of the French government. Lebrun and Cambacérès discussed personal matters, but Cambacérès also kept Lebrun up-to-date on the state of the Empire. ${ }^{13}$ Apart from tapping into his Parisian network, Lebrun started corresponding with key figures in the Dutch executive, administration, and army. He saw his job-as he wrote to Vice-Admiral Jan Hendrik van Kinsbergen - as 'rebuilding that what time and passions have destroyed'. ${ }^{14}$ Lebrun's duties as Lieutenant General more or less ended with Napoleon's decree of 18 October 1810. Since initially the idea had been to 'simply' incorporate the former Kingdom of Holland, and then implement Napoleonic governance without regard to local conditions, Lebrun was hoping to return to Paris within a few months.

Lieutenant General Lebrun had never been very enthusiastic about his tasks in the Netherlands, but carried them out willingly. It must have been reassuring that the decree was silent on the matter who would be appointed General-Governor. Lebrun reminded Napoleon that his duties ended on 1 January 1811, and stress that he was longing to retire. He feared being ridiculed or being viewed with pity if he would stay any longer in Holland. ${ }^{15}$ But much against his will Lebrun was appointed gouverneur général. Lebrun asked Napoleon to be relieved of his duties due to his old age: 'life has no prize for me'. ${ }^{16}$ For several weeks, the newly appointed gouverneur général argued that he was too old, did not have the vigor, and would

${ }^{12}$ Ribberink, 'Lebrun en de homines novi', 132-133.

${ }^{13}$ Johan Joor, 'De behoefte aan een correspondentie 'fidèle et sûre'. Een blik in de briefwisseling tussen Charles François Lebrun en Jean-Jacques Régis Cambacérès, 1810-1813', in: G. Boink et al. ed., Een kapitaal aan kennis: Liber Amicorum Sierk Plantinga (2013) 265-269.

${ }^{14}$ Lebrun to Van Kinsbergen, 24 October 1810. A.-C. Lebrun, 'Notice biographique', in: A.-C. Lebrun ed., Opinions, rapports, et choix d'écrits politiques de Charles-Francois Lebrun, duc de Plaisance (Paris 1829) 136.

${ }^{15}$ Lebrun to Napoleon, 13 December 1810. H. T. Colenbrander ed., Gedenkstukken der algemeene geschiedenis van Nederland van 1795 tot 1840. VI: Inlijving en opstand 1810-1813 ('s-Gravenhage 1912) no. 155.

${ }^{16}$ Lebrun to Napoleon, 17 December 1810. Ibid., no. 158. 
be very grateful if he would be relieved of the governmental burden. ${ }^{17}$ But Napoleon insisted.

Concurrently, the Hanseatic departments were incorporated. ${ }^{18}$ With the stroke of a pen, three departments were formed from the amalgam of territories in Northwest Germany. Contrary to the Netherlands, the decree did not mention a gouvernement, but it installed a commission de gouvernement, which was tasked with preparing the three Hanseatic departments for integration and conserving 'the interests' of the Empire. The commission was to finish its work on 1 July 1811 (later extended to 1 January 1812). Marshall Louis-Nicolas Davout was appointed as GeneralGovernor. Compared to the establishment of the Dutch GeneralGovernment, the decree was rather short and Davout's formal powers were more modest than Charles-François Lebrun's. Davout was primarily responsible for commanding the French troops, and for general keeping of law and order. Procedurally, he presided the commission and signed all acts passed by the commissioners. Significantly, whereas High Dignitary Lebrun corresponded directly with the Emperor, Davout was expected to correspond with the Ministers of the Interior and Finances. ${ }^{19}$

Peculiarly, an imperial decree (26 December 1810) on the administrative reorganization of Northwest Germany was never published in the Bulletin des lois, therefore it did not have force of law. Nevertheless, this decree, having many similarities with the Dutch decree, defined important aspects of the new system of governance like the demarcation of the new departments, its personnel, the introduction of conscription, the creation of a directeur de police, and the recognition of the German (and Dutch) language. ${ }^{20}$ In the course of 1811 this omission (or perhaps an intended procedural 'error') would lead to discussions whether the decree should be interpreted as a fixed law or, less strictly, 'only as an instruction'. ${ }^{21}$ The

${ }^{17}$ Lebrun to Napoleon, 7 January 1811. Ibid., no. 162.

${ }^{18}$ Journal de Paris (1810). 20 December 1810; Helmut Stubbe da Luz, 'Statthalterstatute. Grundlegende Normenkataloge für Dependancen und Provinzen', in: H. Stubbe da Luz ed., Statthalterregimes-Napoleons Generalgouvernements in Italien, Holland und Deutschland (1808-1814) (Hamburg 2016) 263-268.

${ }^{19}$ For example, Ch. De Mazade ed., Correspondance du maréchal Davout, prince d'Eckmühl. Ses commandements, son ministère, 1801-1815. Tome troisième (Paris 1885); Annie Jourdan ed., Correspondance générale. Tome dixième. Un Grand Empire, mars 1810-mars 1811 (Paris 2014) no. 2579.

${ }^{20}$ Gazette nationale ou le Moniteur universel (1810), 31 December 1810.

${ }^{21}$ Antoinette Joulia, 'Ein französischer Verwaltungsbezirk in Deutschland: Das Oberemsdepartement (1810-1813)', Osnabrücker Mitteilungen 80 (1973) 33. 
concrete tasks of the commission and the decision-making discretion assigned to it were not precisely defined. All measures were to be communicated to Paris; the members of the commission de gouvernement were at the same time granted a certain liberty. ${ }^{22}$

Indeed, his memoires the French fiscal inspecteur d'arrondissement Alexandre Boudet de Puymaigre recalls the rather unorganized start of Napoleonic integration attempts in Northwest Germany. Boudet de Puymaigre considered this to have been a conscious choice. He implies that French authorities believed it was 'more convenient to pressure the land under a military and exceptional regime' and therefore purposely delayed the formal integration into the Empire. ${ }^{23}$ The imprecise legal basis seems to be have been deliberate, and attributed to the ad hoc nature of the initial incorporation and integration of Northwest Germany.

Louis-Nicolas Davout, 31 years younger than his counterpart in Amsterdam, did not have to be persuaded. Governor Davout's abilities were generally recognized, and his loyalty to France was undisputed. At the same time, the Marshall was seen by many as arrogant and pompous, certainly among non-military men. According to inspecteur d'arrondissement De Boudet de Puymaigre, Davout demanded to be treated as a highness. His wide powers and status in a way made him a 'satrap' or 'pasha'. ${ }^{24}$ French subprefect De Barthélemy would write in later life that Davout 'governed these provinces in an absolute way; living as a sovereign, having himself being addressed to as Altesse or Monseigneur' ${ }^{25}$ And the first impression of the President of the Imperial Court in Hamburg, Hercule de Serre, on arrival in Hamburg, was that Davout lived 'like a Prince, having a veritable court and is placed above all other authorities'. ${ }^{26}$ But Davout undoubtedly had many admirers. Reports of the time suggest not all Frenchmen in Northwest Germany were that outspoken about him. ${ }^{27}$

${ }^{22}$ Ibid., 35 .

${ }^{23}$ Alexandre Boudet de Puymaigre, Souvenirs sur l'émigration, l'empire et la restauration (Paris 1884) 127.

${ }^{24}$ Ibid., 129.

${ }^{25}$ Hyacinthe-Claude-Félix de Barthélemy, Souvenirs d'un ancien préfet (1787-1848) (Paris 1886) 79-80.

${ }^{26}$ De Serre to his mother, 19 August 1811. G. de Serre ed., Correspondance du comte de Serre (1796-1824). Tome premier (Paris 1876) 89.

${ }^{27}$ Joseph Fiévée, Correspondance et relations de J. Fiévée avec Bonaparte, premier consul et empereur pendant onze années (1802 à 1813) (Bruxelles 1837) 159. 


\section{THE INTENDANTS}

Directly under the General-Governors came so-called intendants. On the one hand, intendant was a term from the Old Regime. It denoted an official who was appointed by the king to perform a certain task in a designated part of the realm. Under Napoleon, on the other hand, intendant was used as an appellation of a specific civil functionary within the army. ${ }^{28}$ So, the profile of Intendant was multi-interpretable, which may have contributed to its usage in different circumstances.

Regarding the Netherlands, Napoleon had repeatedly stressed that he not want to send over too many French civil administrators, nor indifferently replace Dutch institutions. Governor Lebrun agreed that the only way to implement the Napoleonic system of governance accurately and quickly, was to rely on men who knew 'the tradition of Dutch government', the language, and personnel. Otherwise, the French would waste much time, rendering their rule ineffective. ${ }^{29}$ However, introducing Napoleonic governance without the aid of French officials altogether, would also be inefficient. Take the figure of the donanier, who upheld the Continental System. Such men, Napoleon and Lebrun agreed, should primarily be French. ${ }^{30}$

The two main posts in Lebrun's General-Government were those of intendant de l'intérieur and intendant des finances. Originally, the idea had been to create one intendancy for both the Interior and Finances, but within a few weeks it was decided that these important issues needed to be distributed over two separate intendants in Amsterdam.

A Frenchman was to be in charge of the introduction of the French administrative system. Lebrun was therefore assisted by intendant de l'intérieur François Jean-Baptiste Dalphonse, who, prior to his Dutch vocation, had been prefect in France-in 1800 of the Indre department and from 1804 onward of the Gard department. Although Dalphonse was member of the gouvernement général, he was accountable to the Minister of the Interior. He was strictly speaking not an administrator, but had an

\footnotetext{
${ }^{28}$ Kolanović and Šumrada ed., Napoleon et son administration, 26-27; Catherine Lecomte, 'De l'intendant au préfet: rupture ou continuité ?', in: E. Pelisson ed., La loi du 28 pluviôse an VIII deux cents ans après : survivance ou pérennité ? (Paris 2000) 12.

${ }^{29}$ Lebrun to Napoleon, 28 November 1810. Colenbrander ed., Gedenkstukken VI, no. 146 .

${ }^{30}$ Annie Jourdan, 'La réunion de la Hollande à la France: histoire d'un processus', in: F. Antoine et al. ed., L’Empire napoléonien. Une expérience européenne? (Paris 2014) 144.
} 
advisory and coordinating role. The prefects in the Dutch departments were therefore to send all correspondence that did not concern (administrative) integration directly to relevant French institutions in Paris. François Dalphonse turned out to be a vital connection. He passed orders from Paris on to the prefects, briefed ministers on the Dutch situation, and explained French legislation to the Dutch. Thus, he ensured that the French administrative system, and thereby, in a larger sense, the Napoleonic system of governance, functioned. He took great pains at getting to know local culture and traditions. ${ }^{31}$ Without Dalphonse the integration would, most probably, have been even more complicated.

The office of intendant des finances was held by Alexander Gogel, an experienced financial expert, who had worked out a modern progressive taxation system in 1806. Former revolutionary Gogel, an ideologically driven politician, had succeed in giving the Dutch state a sound financial foundation. He strove to transform the old federal Republic into a unitary state. Napoleon was impressed by Gogel and had made him member of his Conseil d'État. Initially, he was entrusted with both finances and internal affairs, but it made more sense to entrust the administrative integration of the Netherlands to an experienced French ex-prefect like Dalphonse. Alexander Gogel's function as Intendant was intended to be temporary. He was given relatively much freedom, although he always remained subordinate to the Minister of Finance in Paris. ${ }^{32} \mathrm{He}$ regretted the loss of Dutch independence, but considered integration to be the only option to prevent the progress made by the Revolution from being lost. ${ }^{33} \mathrm{He}$ tried to promote Dutch interests as best he could, in his advisory and coordinating role. Gogel advocated a slow fiscal integration. His motives were not ideological or 'nationalistic'. His motivation was financial (new French taxes would be lower, thus put a strain on the budget) and practical (Dutch had to acquaint themselves with French fiscal legislation, and he feared 'inexperienced' Dutch tax employees would be replaced by French

${ }^{31} \mathrm{~J}$. Roelevink, Onderzoeksgids bestuur en administratie van de Bataafs-Franse tijd, 1795-1813 (Den Haag 2012) 265-267.

${ }^{32}$ H. T. Colenbrander, Inlijving en opstand (Amsterdam 1913) 57; Johanna W. A. Naber, Overheersching en vrijwording: geschiedenis van Nederland tijdens de inlijving bij Frankrijk, juli 1810-november 1813 (Haarlem 1913) 34.

${ }^{33}$ Jan Postma, Alexander Gogel (1765-1821): grondlegger van de Nederlandse staat (Hilversum 2017) 275-276. 
officials). ${ }^{34}$ The French head of police in the Netherlands, Paul Étienne de Villiers du Terrage, was not positive about Intendant Alexander Gogel. De Villiers du Terrage suspected that Gogel tried to prevent integration. But since few people knew the fiscal 'labyrinth' as good as Gogel, his obstruction was tolerated, claimed De Villiers du Terrage. ${ }^{35}$ Gradually, Gogel were entrusted fewer tasks, and he had to do with a smaller staff.

Like his colleague in Amsterdam, Davout was aided by two intendants, but in his case an Intendant for the Interior and Finances, and one for the implementation of the French judiciary. Note that the latter function did not exist in the Netherlands. There, national legal harmonization had been initiated from the Batavian Revolution onward. King Louis Bonaparte had successfully reformed Dutch legal institutions, which could be adapted to French models without much trouble. ${ }^{36}$

The intendancy of the Interior and Finances was entrusted to Councilor of State René (Mouchard) de Chaban. Like many Frenchmen that were sent northbound, René de Chaban was a man of administrative experience in many part of the Empire. Historian Aurélien Lignereux has referred to him as a 'veritable annexation specialist'. ${ }^{37}$ Having started in the French heartland, he had been subprefect of Vendôme (in his native department of Loir-et-Cher) in 1798. Subsequently, he had been appointed prefect of the Rhenish department Rhin-et-Moselle, and prefect of the 'Belgian' Dyle department. In 1808 he had been appointed member of the Napoleonic junta in Toscana, and as such had been co-responsible for the organization of the three départements de la Toscane. ${ }^{38}$ Like his counterpart Dalphonse in Amsterdam, De Chaban was generally well-liked, certainly in comparison to his superior Governor Davout. Subprefect De Barthélemy would later write that De Chaban character was 'gentle and moderate', and thereby 'corrected, to a certain extent, the consequences of the too authoritarian character' of Davout. According to De Barthélemy,

${ }^{34}$ Jan Postma, 'Alexander Gogel: bouwer van de eenheidsstaat', Pro Memorie 12 (2010) 56-86.

${ }^{35}$ De Villiers du Terrage to Savary, 9 February 1811. Colenbrander ed., Gedenkstukken VI, no. 735 .

${ }^{36}$ Martijn van der Burg, 'Cultural and legal transfer in Napoleonic Europe: Codification of Dutch civil law as a cross-national process', Comparative Legal History 3 (2015) 85-109. https://doi.org/10.1080/2049677X.2015.1041727

${ }^{37}$ Lignereux, L'Empire des Français, 354.

${ }^{38}$ Joulia, 'Ein französischer Verwaltungsbezirk', 36-37; Stuart Woolf, Napoleon's integration of Europe (London and New York 1991) 73. 
De Chaban softened many measures that could have led to discontent among the Germans. ${ }^{39}$

Indeed, in his correspondence with Davout, De Chaban underlined that a moderate approach was needed: 'The new subjects have to be persuaded', therefore French officials should try to win public opinion, while still remaining firm. ${ }^{40}$ For instance, unlike Davout, De Chaban dreaded the French police's 'irresistible tendency' to extend its authority: 'Their surveillance is indispensable, but they have limits to which they must rigorously confine themselves'. ${ }^{41}$ But whereas Dalphonse was genuinely interested in Dutch culture, De Chaban had less affinity with the Germans. He considered Northwest Germany incomparable with other incorporated regions, he wrote the Minister of the Interior. The inhabitants did not know a common fatherland, but were said to be driven by personal interest. The French could help the inhabitants to reorient themselves. ${ }^{42}$ Likewise, various contemporaries characterized De Chaban as well-loved, but also as somewhat patriachical. ${ }^{43}$ President of the Imperial Court in Hamburg, Hercule de Serre noted that De Chaban overshadowed other French officials and favored his own area of policy: the administration. ${ }^{44}$ State Councilor Joseph Fiévée-who was skeptical about the commission de gouvernement-considered De Chaban as potentially having many good qualities. But since his position as commission member was, in Fiévée eye's, 'false', given the awkward position of the commission, De Chaban was primarily concerned with his own job safety. ${ }^{45}$ Whether or not these characterizations are entirely truthful, De Chaban indeed enjoyed a large degree of autonomy concerning the implementation of Napoleonic governance. He was given relatively much freedom how to interpret the French model in a German context. ${ }^{46}$

\footnotetext{
${ }^{39}$ Barthélemy, Souvenirs, 79-80.

${ }^{40}$ Burghart Schmidt, Hamburg im Zeitalter der Französischen Revolution und Napoleons (1789-1813) (Hamburg 1998) 494.

${ }^{41}$ De Chaban to Davout, 16 April 1812. Georges Servières, L'Allemagne française sous Napoléon Ier, d'après des documents inédits tirés des Archives Nationales et des Archives des Affaires Étrangères (Paris 1904) 479-480.

${ }^{42}$ Schmidt, Hamburg, 490.

${ }^{43}$ Boudet de Puymaigre, Souvenirs sur l'émigration, 130, 134.

${ }^{44}$ De Serre to his mother, 19 August 1811. De Serre ed., Correspondance du comte de Serre I, 89.

${ }^{45}$ Fiévée, Correspondance et relations, 159.

${ }^{46}$ Joulia, 'Ein französischer Verwaltungsbezirk', 36-37.
} 
The second intendant, Louis-Joseph Faure, was responsible for the reorganization of the judiciary in Northwest Germany, and more broadly the legal integration of Northwest Germany into the Napoleonic Empire. Intendant Faure was a jurist with much experience. He had been a lawyer during the old regime and had become politically active during the French Revolution. Faure had been member of the Council of Five Hundred, and after Napoleon's coup d'état, of the Tribunate. With the dissolution of the Tribunate in 1807, Faure was appointed member of the legislative section of the Council of State. As a Counselor, he had worked on the codification of French criminal law, which had resulted in the Code pénal. ${ }^{47}$ Given his expertise, Faure was primarily concerned with, firstly, the implementation with French law in Northwest Germany, and secondly, the reorganization of the judiciary along French lines. ${ }^{48}$ Whereas Davout was primarily accountable to the Minister of War, and De Chaban to the Ministers of the Interior and Finances, Faure answered to the Minister of Justice. ${ }^{49}$ LouisJoseph Faure seems to have been a hard, but quiet worker. Fellow jurist Hercule de Serre characterized Faure as 'timid' and certainly not the most influential member of the government in Hamburg. ${ }^{50}$ Joseph Fiévée described him as a 'modest' official, who was content with completing his tasks. ${ }^{51}$

\section{Conflicting Mandates}

The Governors and the Intendants were not the only high officials that were appointed in Amsterdam and Hamburg. Other representatives of the central state received their proper orders from Paris, but of course also had to take into account the policies of the intermediary governments. There were many conflicts of competence within the Napoleonic state machinery. The Ministries of the Interior, General Police, War, Finance and Justice each strove to assert power over the farthest corners of the Empire.

\footnotetext{
${ }^{47}$ Jean Vidalenc, 'Les 'départements hanséatiques' et l'administration napoléonienne', Francia 1 (1973) 427; Swantje Naumann and Helmut Stubbe da Luz, Die französischen Besatzer in Hamburg. Zengnisse zu den Jahren 1811-1814 (Hamburg 2013) 251.

${ }^{48}$ Joulia, 'Ein französischer Verwaltungsbezirk', 36.

${ }^{49}$ Ibid., 35.

${ }^{50}$ De Serre to his mother, 19 August 1811. De Serre ed., Correspondance du comte de Serre I, 89.

${ }^{51}$ Fiévée, Correspondance et relations, 157.
} 
These state bodies often did not cooperate well, and often had incompatible ideas about integration of the North.

An influential Frenchman in Amsterdam was aforementioned directeur général de la police Paul Étienne de Villiers du Terrage who led the extensive police force that was established in the Dutch departments in 1811. Before his appointment as General Director of Police De Villiers du Terrage, a protégé of Pierre-François Réal (Director of the first police division), had served as General Commissioner in Boulogne-sur-Mer. De Villiers du Terrage was one of five Directors-General that were employed exclusively in incorporated departments: Turin, Rome, Tuscany, Hamburg, and Amsterdam. His tasks and duties were also modeled on the organization of the Transalpin departments. De Villiers du Terrage put much effort in creating a loyal and repressive police force. ${ }^{52}$ His police formed part of a large and rather autonomous organization, accountable to the Minister of Police, Anne Jean Marie René Savary. De Villiers du Terrage was one of Savary's most zealous servants, but constantly faced opposition from Lebrun and Dalphonse. It appears from his correspondence with colleagues in Paris that he suffered severely; Pierre-François Réal sent him positive letters hoping to encourage De Villiers du Terrage to continue his work. ${ }^{53}$ In his letters, De Villiers du Terrage called Charles-François Lebrun a 'vieillard irascible': a grumpy old man. It annoyed him that he was obliged show respect for Lebrun. ${ }^{54}$ While he and his colleagues did their utmost to implement the wishes of the emperor, De Villiers wrote, Governor Lebrun took ample time to speak to complaining Dutchmen and make all kinds of promises. Lebrun's presence greatly curtailed his authority. De Villiers likened himself therefore to a 'bird trapped by glue'. ${ }^{5}$ The feelings were mutual: Lebrun disliked De Villiers and refused to communicate directly with him. ${ }^{56}$

Charles-François Lebrun also worked with some less prominent directeurs that were associated with institutions in Paris, such as Directeur

\footnotetext{
${ }^{52}$ Martijn van der Burg, 'La police napoléonienne dans les départements néerlandais: entre tradition et modernité (1795-1820)', in: F. Antoine et al. ed., L'Empire napoléonien. Une expérience européenne? (Paris 2014) 261-263. https://doi.org/10.17613/wd7c-e226

${ }^{53}$ Réal to Deviliers, 31 March 1811. Auguste de Caumont la Force, L'architrésorier Lebrun, gouverneur de la Hollande, 1810-1813 (Paris 1907) 272-273.

${ }^{54}$ De Villiers du Terrage to Réal, 4 November 1811. Colenbrander ed., Gedenkstukken VI, no. 777 .

${ }^{55}$ De Villiers du Terrage to Savary, 12 March 1811. Ibid., 742.

${ }^{56}$ Jourdan, 'La réunion de la Hollande à la France', 149.
} 
des ponts et chaussées Johan Hendrik Mollerus, Directeur de la caisse central Robert Voûte, and Directeur du Grand Livre de la Dette publique Cornelis Charles Six van Oterleek-all Dutchmen. ${ }^{57}$ Initially, the Dutch departments received a directeur-principal des donanes. Customs was, of course, an important matter for the Napoleonic authorities. Contrary to other branches of the state apparatus in Holland, this crucial task was not entrusted to Dutch collaborators; donaniers had to be Frenchmen. ${ }^{58}$ The erudite linguist and statistician Charles Étienne Coquebert de Montbret was appointed as Director. Coquebert de Montbret had held various diplomatic functions in Hamburg in the 1770s and 1780s, primarily that of Consul General to the Hanseatic towns. Coquebert de Montbret had traveled Europe and was fluent in German. ${ }^{59} \mathrm{He}$ was supposed to function as intermediate link between the Directorate General in Paris and the customs officials in the Dutch departments. Coquebert de Montbret lacked experience in this field, and resented the irregularities among customs officers, which he could not prevent as he had little powers compared to the authorities in Paris. ${ }^{60}$ From April 1812 onward the donaniers in Holland (with headquarters stationed in Amsterdam, Emden, Groningen, and Rotterdam) received their orders directly from France. ${ }^{61}$

The composition of the intermediary government in Northwest Germany did not exactly follow that of the Dutch departments. Apart from the Governor and the Intendants, the commission in Hamburg was formed by five auditeurs from the Council of State. Claude-Auguste Petit de Beauverger was appointed secrétaire-général. Jules David and Marie Louis François Constant Himbert de Flégny assisted Intendant De Chaban, and Dagobert de Salomon and Beckmann-Schore assisted Intendant Faure. After several months, most of them were employed as

\footnotetext{
${ }^{57}$ Roelevink, Onderzoeksgids, 253-280.
}

${ }^{58}$ Jourdan, 'La réunion de la Hollande à la France', 144.

${ }^{59}$ Aurélien Lignereux, 'La langue des policiers: pratiques linguistiques, politique de recrutement et culture professionnelle dans les départements annexés', in: F. Antoine et al. ed., L'Empire napoléonien. Une expérience européenne? (Paris 2014) 384.

${ }^{60}$ Marie Du Mesnil, Mémoires sur le Prince Le Brun, Duc de Plaissance et sur les événemens auxquels il prit par sous les parlemens, la révolution, le consulat et l'empire (Paris 1828) 370-371.

${ }^{61}$ Johan Joor, De Adelaar en het Lam: onrust, opruiing en onwilligheid in Nederland ten tijde van het Koninkrijk Holland en de inlijping bij het Franse keizerrijk (1806-1813) (Amsterdam 2000) 426-427. 
prefect or subprefect to put the integration program of the commission de gouvernement into practice (see Chap. 6).

Louis-Philibert Brun d'Aubignosc, as directeur-générale de la police, was responsible for policing Northwest Germany. A skilled and committed servant, Aubignosc had long been active in the army. He was captured during Napoleon's Egypt campaign, and later gained the trust of State Councilor Pierre Daru, who in 1806 became General Director of the Grande Armée led against Prussia. Aubignosc worked in the newly conquered Berlin, and distinguished himself by a well-founded report on Prussian finance. In 1809, at Daru's instigation, he became general director for occupied Hannover, and later for the Duchy of Lauenburg. From early on, Aubignosc was keen on enlarging the Empire, sending memorandums to recommend the incorporation of Northwest Germany. His activities contributed to his appointment in January 1811 Hamburg, was later promoted to directeur-générale. ${ }^{62}$

Whereas Amsterdam's police director was on good terms with Minister of Police Savary, and not with the General-Governor, in Hamburg the situation was the other way round. Minister Savary had a low opinion of Aubignosc. Nevertheless, Aubignosc worked closely together with Davout. Davout repeatedly tried to convince Savary that Augbignosc was doing an excellent job, but eventually had to turn to the Emperor to express support for Aubignosc. Aubignosc complained about the lack of manpower and financial means. He had at his disposal a relatively limited number of employees. Also, he had to share police commissioners with the respective maires. Minister Savary was not very cooperative in overcoming these problems. Therefore, Davout's troops actively assisted Aubignosc's men. Aubignosc also encountered opposition from French officials stationed in Hamburg who not keen on enlarging Aubignosc's powers, because they were involved in corruption. ${ }^{63}$

In Hamburg, Consul Jean-Jacques-Sébastien Le Roy, in a seemingly superfluous office, became correspondent for the French Foreign Ministry. Veteran Le Roy had joined the French naval forces as a young man, became a naval engineer in 1778, took part in the American War of Independence, and had been active as a diplomat in Constantinople. After taking part in

${ }^{62}$ Naumann and Stubbe da Luz, Die französischen Besatzer, 68, 274-275.

${ }^{63}$ Burghart Schmidt, 'Die französische Polizei in Norddeutschland: Die Berichte des Generalpolizeidirektors d'Aubignosc aus den Jahren 1811-1814', Francia 26 (1999) 93-114; Naumann and Stubbe da Luz, Die französischen Besatzer, 68, 274-275. 
Napoleon's expedition to Egypt, he was assigned to the Foreign Ministry. And after the Consul Generalship in Cadiz, Le Roy was sent to Hamburg to report on everything going on in Northern Europe. Remarkably, alongside the hybrid military-civil authorities, a de facto representative of the Ministry of Foreign Affairs was active, as if Northwest Germany remained a foreign state. There was enough to observe in the newly incorporated city that should not be left to the general director of the police, Aubignosc, alone. Importantly, Le Roy became a member of the Conseil spécial set up in Hamburg to monitor the Continental System. ${ }^{64}$ Furthermore, the activities of the aforementioned persons touched those of Joseph Eudel, customs director in Hamburg. Eudel had already come to the Hanseatic cities in January 1807, together with his corps of customs officers. ${ }^{65}$

The above shows that Frenchmen that were sent to the North formed a heterogeneous group. They did not always get along, which was all the more difficult since their activities could overlap. Tensions within the Napoleonic state apparatus did not go unnoticed locally. According to Abraham Ampt, a police commissioner in The Hague, the Napoleonic government deliberately 'encourages small skirmishes' between administration, army, and police. The central government hoped that conflicts would keep the people in the field sharp, Ampt observed. Moreover, it was thought these antagonisms would prevent administrators, policemen, and other officials from forming a local force against the central government. ${ }^{66}$ For the Parisian authorities this state of affairs had another advantage: the separate threads of the web allowed the government to obtain information from varied sources, which provided a more complete view of the situation at the local level. ${ }^{67}$ This was especially welcome concerning new pays réunies.

\footnotetext{
${ }^{64}$ Naumann and Stubbe da Luz, Die französischen Besatzer, 59-61.

${ }^{65}$ Silvia Marzagalli, Les boulevards de la fraude: le négoce maritime et le blocus continental, 1806-1813: Bordeaux, Hambourg, Livourne (Villeneuve d'Ascq 1999) 192.

${ }^{66}$ Naber, Overheersching en vrijwording, 68.

${ }^{67}$ Pierre Henry, Histoire des préfets: Cent cinquante ans d'administration provinciale, 1800-1950 (Paris 1950) 53.
} 


\section{DeVelopment of the InTERmediary Bodies}

Early 1811, the first phase of integration was completed in the Dutch departments. Now, Charles-François Lebrun was able to delegate most of the day-to-day management to the intendants. Therefore, he was less tied to the third capital. With Napoleon's permission, he relocated to Huis ten Bosch in The Hague - the former residence of the Oranges and briefly the palace of King Louis Napoleon. Between 1811 and 1813 he settled alternately in Amsterdam and The Hague. ${ }^{68}$ Contemporaries remarked that Governor Lebrun increasingly played the role of 'good old man', on the background, to appease the Dutch. ${ }^{69}$ There may have been a link between Lebrun's stay in The Hague and simultaneous severe actions of French military commissions against reluctant Dutch conscripts. ${ }^{70}$ Responding to this repression, Lebrun argued that true justice did not demand blood, but examples. Blood spilled 'without absolute necessity' would only produce more hatred and revolt. ${ }^{71}$

Throughout, Charles-François Lebrun was willing to listen to the concerns of the Dutch. He had the ability to cope with Napoleon's high demands and, if necessary, he did not hesitate to tell Napoleon the truth. For instance, 'Gentle measures are needed', Lebrun frequently insisted with Napoleon, 'those work wonders with the Dutch'. ${ }^{72}$ Yet, Lebrun always remained loyal to Napoleon and did not tolerate widespread opposition.

The shock Dutch republicans had experienced in 1806, now befell the inhabitants of the Hanseatic cities. Davout made it clear that the North Germans had to make no illusions-all autonomy was lost. Obviously, French influence had been considerable for years, but the definitive loss of republicanism fell heavily on citizens. ${ }^{73}$ Hamburger Karl Gries regretted that 'out of Republicans we have become Subjects'. Proud citizens, were attached to their form of government, not least because it was so old, Gries claimed. But he admitted that, despite all the laudable efforts to preserve civic republican freedom, form of government had become

${ }^{68}$ Lebrun to Napoleon, 1 February 1811; Lebrun to Napoleon, 26 May 1811. Archives nationales, Paris, AF IV 1724, pièces 54, 298.

${ }^{69}$ Maarten W. van Boven ed., Afscheid van de wereld. Het eigen levensverhaal van Boudewijn Donker Curtius, politicus, advocaat en rechter in de Bataafs-Franse tijd (Hilversum 2010) 116.

${ }^{70}$ Bart Verheijen, Nederland onder Napoleon: partijstrijd en natievorming 1801-1813 (Nijmegen 2017) 203.

${ }^{71}$ Lebrun, 'Notice biographique', 144.

${ }^{72}$ Lebrun to Napoleon, 2 February 1812. Colenbrander ed., Gedenkstukken VI, no. 315.

${ }^{73}$ Katherine Aaslestad, Place and politics: Local identity, civic culture and German nationalism in North Germany during the Revolutionary Era (Leiden 2005) 245-246. 
archaic. ${ }^{74}$ Tellingly, one of the first acts of the Commission was abolishing the urban Senates, the backbone of the age-old Hanseatic governance system. Davout was keen to dispose completely of the old urban form of government, but many of the civil servants were retained, also as a gesture toward the administrative elite. ${ }^{75}$ Reactions were mixed. According to Davout, the old officials settled with 'resignation and submissiveness'. However, police accounts reported dissatisfied reactions from the population, such as the nightly removal of posters with the Commission's official ordinances. In the hinterland, popular responses seem to have been more moderate. ${ }^{76}$

When the organization plans finished, auditeurs Himbert de Flégny and Beckmann-Schore personally brought all documentation to Paris, to submit it to Napoleon. If the Emperor approved it before 25 June, the French government could enter into force punctually on 1 July $1811 .{ }^{77}$ With an imperial decree, the workings of the intermediate government were finally determined. The Commission would continue its work from 1 January 1812 onward as the gouvernement général of the Hanseatic departments. The decree displayed many similarities with the manner in which the Dutch situation was regulated. For instance, a directeur-général de police was established, similar to the one in Amsterdam, which, in turn, was modeled on the Italian example. The Governor still was responsible for 'high police' and 'exercises general supervision over all military, civilian, and administrative authorities, but without the power to modify or suspend any order given by our ministers ${ }^{78}$ - unlike Lebrun, who in the chain of command stood directly under Napoleon.

In Hamburg, from September 1811 onward, French State Counselor Joseph Fiévée was active as member of a liquidation commission, which took care of the debts of former governments. Fiévée was critical of the intermediary government's activities and its competences. There was no clear division of competences and tasks-all the more so because the Commission's term of office had not yet come to an end when Fiévée had

\footnotetext{
${ }^{74}$ Karl Gries to Diederich Gries, 28-30 March 1811. Heinrich Reincke, 'Aus dem Briefwechsel von Karl und Diederich Gries, 1796-1819', Zeitschrift des Vereins für Hamburgische Geschichte 25 (1924) 17.

${ }^{75}$ Schmidt, Hamburg, 437.

${ }^{76}$ Joulia, 'Ein französischer Verwaltungsbezirk', 38 .

${ }^{77}$ Schmidt, Hamburg, 489.

${ }^{78}$ Imperial decree of 4 July 1811. Duvergier, Collection complète des lois... XVII, 463-480.
} 
to start his work. ${ }^{79} \mathrm{He}$ also pointed to a power struggle between the commission and their superiors in Paris. Knowing their formal authority was questionable, members of the commission de gouvernement, in Fiévée's eyes, struggled to 'retain a portion of power'. ${ }^{80}$

During 1811, the Commission convened in 40 sittings, creating the basic structures for Napoleonic governance. Accordingly, it was considered appropriate to discontinue the Commission's work at the turn of the year. The decree of 4 July had already transferred numerous powers to the prefects, with the General-Governor remaining as the higher supervisory authority. Even after the dissolution of the Commission, the GeneralGovernor remained in charge of the military high command and exercised supreme supervision over 'high police' and all government bodies, provided he would neither amend or postpone ministerial decrees, nor exercise influence on the administration of justice. Davout's position emphasized that the territories still required special control. ${ }^{81}$ His primary task in Hamburg was the build-up of a strong military force, with the aim of conquering the Russian Empire. Rumor had it he was hoping to receive the title of King of Poland when, after defeating the Tsar's troops. Davout left Hamburg with his army in March 1812, but was not formally released from his duties. ${ }^{82}$

Antoinette Joulia has explained the persistence of the Northwest German intermediary government after 1811 in terms of a shift of roles. Initially, preparing for integration was the primary task, but gradually it became clear this coordinating intermediate body contributed to the governability of the area. Nevertheless, many ambiguities remained, as multiple lines of communication were chosen, just like in the Dutch departments. In principle, prefects primarily dealt with De Chaban or Faure, especially concerning integration difficulties, but in other cases, Paris was called upon as well. ${ }^{83}$

Another parallel can be drawn with the Dutch departments. In Amsterdam, Intendant Dalphonse's role gradually changed in a similar way. Lebrun delegated more and more tasks to Dalphonse, thus maintaining the Intendant of the Interior. For instance, Dalphonse became

\footnotetext{
${ }^{79}$ Naumann and Stubbe da Luz, Die französischen Besatzer, 106, 261-263.

${ }^{80}$ Fiévée, Correspondance et relations, 156.

${ }^{81}$ Schmidt, Hamburg, 498-499.

${ }^{82}$ Naumann and Stubbe da Luz, Die französischen Besatzer, 227-228.

${ }^{83}$ Joulia, 'Ein französischer Verwaltungsbezirk', 35, 38.
} 
responsible for the reform of poverty institutions, for managing the relations with the various church congregations in the Netherlands, and for a statistical analysis of the Dutch departments. ${ }^{84}$ Like Lebrun, Dalphonse was accepted rather quickly by the Dutch elite and never abused his powers. While traveling the Dutch departments, he sympathized with the Dutch, and reprimanded corrupt French officials. But he never alienated himself from his compatriots. The baron was loyal to Paris. Dalphonse, like Lebrun, did not tolerate Dutch disobedience. ${ }^{85}$

In Hamburg, Intendant Faure performed his duties swiftly. On 20 August 1811, with the opening of the Imperial Court in Hamburg, under the presidency of Hercule de Serres, the whole of the legislation and legal system of the Empire came into effect in the Hanseatic departments. When Faure's duties in Hamburg ended, Napoleon wanted him to return. Faure was sent to southern France to investigate the penitentiary system. ${ }^{86}$ But Intendant De Chaban remained in Hamburg. Joseph Fiévée characterized De Chaban as someone who became increasingly concerned with his own career. To secure his intendancy, and the substantial financial benefits that came with it, De Chaban accustomed Governor Davout to delegate all matters to him, making himself indispensable, while Davout handled military affairs. ${ }^{87}$

Despite their relative proximity, little interactions occurred between the intermediary bodies in Amsterdam and Hamburg. References to each other were limited to incidents, such as in April 1812. As high military authority in the North, Davout had forbidden the municipalities located within the 31st military division, which included parts of both the presentday Netherlands and Germany, from issuing passports for journeys outside their own department. In doing so, he curtailed the free movement of persons. Thereupon the General-Government in Amsterdam had the authorities in Paris intervene and undo the measures taken by Davout. When the gendarmerie, which employed other demarcations of Holland and Northwest Germany, continued to follow Davout's line, Lebrun's position in the hierarchy was decisive, and he overruled Davout. ${ }^{88}$ Examples of such conflicts between Amsterdam and Hamburg are rare,

\footnotetext{
${ }^{84}$ Roelevink, Onderzoeksgids, 265-267.

${ }^{85}$ Naber, Overheersching en vrijwording, 60-61; Simon Schama, Patriotten en bevrijders: revolutie in de Noordelijke Nederlanden, 1780-1813 (Amsterdam 1989) 714-715.

${ }^{86}$ Naumann and Stubbe da Luz, Die französischen Besatzer, 251.

${ }^{87}$ Fiévée, Correspondance et relations, 159.

${ }^{88}$ Dalphonse to Lebrun, 11 April 1812. Colenbrander ed., Gedenkstukken VI, no. 1254.
} 
but it is nevertheless striking that little or no cooperation took place. The intermediary governments constituted two separate spheres within the Empire, which became visible in conflicts where the lines between them were poorly demarcated, like Lippe and Ostfriesland.

\section{Between Center and Periphery}

In Napoleonic Europe, intermediary governance bodies were plentiful, as potentially effective empire-building instruments. A distinction must be made between 'regular' gouperneurs généraux and the newly crated Grand Dignitaries in the form of a General-Governor. With the establishment of the gouvernement générale de la Hollande, Charles-François Lebrun was, again, awarded an honorary title of Grand Dignitary. This answers the rarely asked question why the intermediary government in Amsterdam did not come with an 'end date', like the one in Hamburg. The General-Government was intrinsically linked to the person Charles-François Lebrun as Grand Dignitary. Arguably, the Dutch departments, as a formally distinct entity within the Empire, would not be disbanded until the decease of Lebrun. Otherwise, the Grand Dignitary would be deprived of his 'fief' (to put it somewhat anachronistically). Given the different status of Davout and his commission, as well as their more restricted duties, this was not the case in Northwest Germany.

During the Empire's expansion in these years, Napoleon preferred to act by decree. The two intermediary governments in the North could build on imperial precedents, but were still quite distinct. The processes by which the respective governments were shaped differed, starting with the choice of Governor. At the time of incorporation, the Emperor was well aware of Lebrun's mild approach to ensuring obedience. Yet, he apparently considered Charles-François Lebrun to be the right man for the Dutch departments. Napoleon was satisfied enough with Lebrun's earlier achieved results, that in December 1810 he definitely entrusted Lebrun with supervising the Netherlands. Or, he could not find anyone else who the Dutch would trust to a similar degree. In any case, Napoleon had no immediate reasons to doubt Lebrun's abilities and the successful completion of the integration process.

Both intermediary bodies of governance were to some extent improvised, but evidence suggests that specifically the incorporation of Northwest Germany intentionally turned out rather unstructured, even chaotic. In Hamburg, the loyalty of hardened soldier Davout was undisputed, but there were doubts about the region's integration in the short 
term. Antoinette Joulia has explained the 'somewhat peculiar form of government' in Northwest Germany in several ways. Napoleon's imperial aspirations, as spiritual heir to the German emperors, is accredited to have played a role. Above all, she has pointed to the perceived 'otherness' of the region (at least from a French perspective), as well as the high degree of heterogeneity of the region. ${ }^{89}$

Notwithstanding all sorts of inconsistencies during the incorporation, the intermediary governments were composed with care. The appointed officials were selected mainly because of their competences. In the Netherlands, the framework that was developed and the personal backgrounds of high officials, implied that the Dutch would be given a certain say. French entrusted more tasks to local collaborators than in Northwest Germany, since it was possible to build on a Dutch system of territorial governance. Comparable administrative bodies were largely lacking in the German territories. Napoleonic officials were more prominent in the Hanseatic departments, there, the involvement of the local personnel was mainly at lower levels.

For a large part of their term of office, the Governors-General were in the background and left the tasks to their subordinates. Both Lebrun and Davout could rely on highly skilled intendants. Nevertheless, it were the governors who chose to support certain persons, or not. Davout and Lebrun made individual choices. The two governors in the North hardly ever joined forces, nor were there permanent close contacts between each other's direct staff.

Major stumbling blocks were located outside the gouvernements généraux. The functioning of the intermediary governments in the North was much more complicated than it would have been, if there had been better cooperation, and a clearer division of tasks between various Napoleonic institutions. The governments were hindered in their work by the fact that administrators, policemen, gendarmes, tax inspectors and prosecutors each corresponded with their own Minister in Paris, and consequently there was no single coherent scheme of integration. This was especially the case in Hamburg, where from the start on many ambiguities were.

All considered, the gouvernements généraux derived their strength from being able to mediate between the needs of the periphery and the demands

\footnotetext{
${ }^{89}$ Joulia, 'Ein französischer Verwaltungsbezirk', 32.
} 
of the imperial core. However, this entailed that, so remote from Paris, many actors competed for influence and thus for the control of the integration process. And, of course, integration was not confined to Amsterdam and Hamburg alone. The prefects in de Dutch and Northwest German departments would therefore become important players; they are the protagonists of the next chapter.

Open Access This chapter is licensed under the terms of the Creative Commons Attribution 4.0 International License (http://creativecommons.org/licenses/ by $/ 4.0 /$ ), which permits use, sharing, adaptation, distribution and reproduction in any medium or format, as long as you give appropriate credit to the original author(s) and the source, provide a link to the Creative Commons licence and indicate if changes were made.

The images or other third party material in this chapter are included in the chapter's Creative Commons licence, unless indicated otherwise in a credit line to the material. If material is not included in the chapter's Creative Commons licence and your intended use is not permitted by statutory regulation or exceeds the permitted use, you will need to obtain permission directly from the copyright holder.

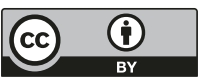

